\title{
Diversity and the dynamics of capitalism
}

\author{
Bruno Amable \\ University of Geneva, Switzerland
}

The diversity of models of capitalism is evolving under the dynamics of capitalism itself, which imposes common trajectories to some institutional forms, such as the financial system or the employment relationship. This article argues that the analysis of the dynamic diversity and commonalities of capitalism can be made by focusing on four elements: the institutions defining the socio-economic model, the dominant social bloc that supports these institutional arrangements, the political actors and the strategy they have for uniting the dominant social bloc, and the public policies, in particular economic policies, implemented by the government.

Keywords: diversity of capitalism, political economy, institutional change, social blocs

JEL codes: $P 16, P 51$

\section{INTRODUCTION}

Whether the diversity of forms in capitalist economies can survive the dynamics of capitalism itself, and in particular globalisation, is a recurring question of comparative capitalism analysis. The answers to this question differ in the respective weight they attribute to the resilience of specifically national institutional forms and the transformative power of the commonalities of capitalism (Streeck 2010). ${ }^{1}$ Comparative political economy (CPE) has proposed various typologies to support the idea that capitalism may exist in differentiated forms (Albert 1991; Amable et al. 1997), the simplest and the most debated one (Howell 2003) being the binary categorisation of OECD economies into coordinated and liberal market economies (CMEs and LMEs) of Hall/Soskice (2001). ${ }^{2}$ This approach ultimately justifies the stability of specific varieties with their ability to be 'competitive'. In this Varieties of Capitalism ( $\mathrm{VoC}$ ) approach, competitiveness may come from two different ways of organising economic activities, namely liberal or 'coordinated'. An intensification of the competitive pressure on national economies, which is an expected consequence of globalisation, should therefore not lead to homogenising market institutions and organisational forms across developed economies, but, on the contrary, should accentuate the differences between LMEs and CMEs because the competitiveness of each variety is supposed to stem from their respective specific forms of market and nonmarket institutions in the comparative institutional advantage view. The conclusion is therefore that the dynamics of capitalism should make LMEs more liberal and CMEs more coordinated.

A more critical stance is to consider that the forces unleashed by capitalism demand more than 'competitiveness', whatever the definition, and, in addition, points out that in certain historical periods, the commonalities of capitalism overcome the specificities

1. See also the special issue of Socio Economic Review, 2011, 9(1) on 'Commonalities of capitalism'.

2. For an alternative theory of capitalism diversity, see Amable (2003). 
of its variegated forms. Capitalism itself has its own dynamics, and a consideration of history would put the differentiation of its specific forms into context. The variety observed by VoC would not be a timeless constant of capitalism but a consequence of the particular forms that capitalist development took after World War II with the diffusion of the Fordist paradigm (Boyer 2005). The international regime of the postWWII period insulated national economies from too strongly homogenising pressures, and it was easier to find different national ways to be competitive when international competition was relatively moderate and international capital movements more restricted. The transformations that took place in recent decades made the coexistence of different models of capitalism - which themselves represent different attempts to get out of the crisis of Fordism - possible for a while. But the neoliberal reforms that gathered momentum after the 1980s had different consequences for the different varieties. The movement of economic liberalisation that affected most national institutions, in particular in the financial sector, changed the respective bargaining powers of labour and capital, to the benefit of the latter for instance. The possibilities for capital to escape from the constraints that formed the structure of the more 'regulated' varieties of capitalism increased considerably. This gave more power for capital to create pressure for institutional change in a certain direction.

The movement of dismantling of the institutions of non-liberal capitalism became almost self-perpetuating because of the complementarities between institutions (Amable 2016). The interplay of the commonalities of capitalism and the diversity of its national forms, which is sustained by national socio-political compromises, paints a picture of capitalism which is neither a stable differentiation nor a uniform homogeneity of institutional forms. There is no unidirectional influence either, whereby the 'forces of globalisation' would impose changes to national institutional structures that would stay purely passive. The common dynamics of capitalism is shaped by decisions taken at the national level, decisions that are themselves taken under the influence of the global economic dynamics.

\section{ANALYSING THE DIVERSITY OF CAPITALISM}

Comparative political economy (CPE) has mostly focused on the institutional differences between the various models of capitalism: the degree of centralisation of wage bargaining, the relative importance of banks or markets in the financial system, etc. Such characterisations are useful for distinguishing varieties of capitalism but meet their limits when it comes to explaining institutional change (or stability) because of their focus on the forms of institutions, at the expense of an investigation of the causes of change. A political economy of capitalism needs a theory of institutions (Amable 2003; Amable/Palombarini 2009) that breaks with economic functionalism.

The analysis of the diversity of capitalism can take four elements into consideration. The first one is of course the socio-economic model. Institutions change by the action of governments and parliaments, and 'structural reforms' redefine the institutions composing a model of capitalism, which is then defined as a set of specific institutional forms. This implies not only the consideration of the differences in the forms of the institutions (type of employment relation, features of the financial system, etc.), but also the interactions between the different institutions. CPE has emphasised that models of capitalism are not more or less random collections of specific institutions but that there are complementarities between them (Aoki 2001; Amable 2016).

With respect to what institutions are complementary (or not) leads to the second element to be taken into consideration. Institutions are not techniques producing economic 
efficiency, whatever that is; they are rules that influence the distribution of economic and political power among social groups. They are the products of a conflictual political process and, as a consequence, their stability is the outcome of political and social compromises (Amable/Palombarini 2009). An important element characterising a particular model of capitalism is the dominant social bloc (DSB), defined as the set of social groups whose most significant expectations are sufficiently satisfied by the institutional structure and the policies implemented for them to support this structure and these policies.

The formation of a dominant social bloc results from a political strategy, and this is the third element to consider. Blocs are made of social groups with different and sometimes diverging expectations regarding institutions or policies, and the groups themselves are not necessarily homogeneous (Amable 2017). The unification of the bloc is the result of the action of political actors consciously looking for support and for mediation between different policy expectations. The mediation that these actors find will result in the constitution of a dominant social bloc and the implementation of a policy compatible with the most important expectations of the bloc.

The fourth element is the part of public policy that does not affect institutions, but is nevertheless instrumental in maintaining the stability of the dominant social bloc. Of particular interest is macroeconomic policy, and particularly budget policy.

Public expenditure and taxation can be used by the government for securing political support, as analysed in political business cycle theory (Kalecki 1943). The complementarity that exists (or not) between institutions of a given model can be extended to a complementarity with economic policies, and the possible complementarities are not necessarily limited to an association between 'conservative' macroeconomic (respectively accommodating) policies and non-liberal (respectively liberal) models of capitalism (Amable/Azizi 2014).

Part of the debate on macroeconomic policy in Europe hinges on the diverging position of the respective governments of France and Germany. Both governments broadly agree with neoliberal reforms (labour-market flexibility, welfare-state retrenchment, etc.) but the French want to supplement these reforms with an accommodating macroeconomic policy whereas the Germans insist on the necessity of fiscal austerity. A more accommodating macroeconomic policy may make it easier to push forward neoliberal reforms by making them more acceptable to the 'losers' of these reforms whereas a conservative macroeconomic policy may make these reforms more difficult to implement (Amable 2009).

\section{COMMONALITIES AGAINST DIVERSITY}

Mainstream CPE (that is, VoC) reconciles commonalities of capitalism, above all globalisation, with diversity by the ability of different varieties to be competitive. But the question is whether the logic of increasing productive specialisation, which is a logical consequence of globalisation, is compatible with enduring institutional differentiation. Globalisation includes two conflicting trends and represents a source of increasing tension. On the one hand, it promotes a productive and trade specialisation that will increase differences across national economic structures; on the other hand, it pushes for an increasing homogenisation of institutional features, either directly (accounting rules, corporate governance, etc.) or indirectly (fiscal competition, multinational firms' strategies, etc.). There is therefore a contradiction between productive differentiation and institutional convergence if one believes that there might be some truth in the comparative institutional advantage story. 
Several aspects of globalisation dampen VoC's optimism regarding enduring diversity. The most prominent aspect of globalisation is financial liberalisation and the increased mobility of capital across countries. In Europe, this took the form of the directive of 1988 which established the freedom of capital mobility not only within the EU, but with respect to extra-European countries too. The dangers of capital mobility for the possibility of a model of capitalism that would not be reduced to its most deregulated expression were already known before the Treaty of Rome was signed. In 1957, Pierre Mendès-France, a leading left-wing politician at the time, delivered a speech before the French parliament where he warned about the consequences of a partial integration that would liberalise capital movements without unification of the tax systems: 'The Common Market is planned to include the freedom of movement for capital ... . Capital has a tendency to leave socialist-leaning countries and this exerts pressure in the direction of relinquishing the socially advanced policies'. ${ }^{3}$ The risks of a race to the bottom have been confirmed in the decades that followed (Genschel 2002), when one looks not only at the drop in corporate tax rates of recent decades but also at the pattern of taxation of countries that strive to maintain a high level of social protection and resort to taxing immobile rather than mobile factors, implying that the tax burden falls on consumption and households rather than profits and firms. A simple aspect of globalisation, increased trade specialisation, has distributional consequences too. This means that globalisation most likely increases inequality ${ }^{4}$ and consequently the need for inequality-reducing policies while at the same time makes the implementation of redistribution more difficult because of the pressure on public policy exerted by tax competition.

Other aspects of the homogenising pressure associated with globalisation concern the regulation of product markets. The consequences of product-market liberalisation for institutional forms in other areas (employment relation for instance) have been investigated in various ways, ${ }^{5}$ but one aspect worth stressing is the pressure for former nationalised firms or public utilities to be privatised in order to allow other firms in the same industry or activity but from different countries to compete with them on supposedly fair terms. The privatisation of these companies has had wide-ranging consequences that change drastically the national socio-economic model in terms of price and service or product quality. The fundamental question that such change poses is again that of the size and role of the public sector.

Privatisations are also instrumental in enhancing flexibility-oriented employment legislation reforms. In some countries, public employment acts as an employment quality standard that can be used as a reference for employees' expectations regarding their own employment conditions. In many countries, privatisation of public services was accompanied by changes in the employment relation of previously state-owned companies that led to more flexibility and precariousness for employees. This had an impact on the expectations of employers and employees of the private sector, because of the waning or disappearance of the public employment standard.

These cases illustrate the ambiguity of globalisation when it comes to exerting pressure for institutional change. The concerned changes, privatisation, are not direct consequences of the globalisation, but part of a specific strategy to deepen the internationalisation of previously nationalised companies and public utilities, a strategy decided at the national level, even if not exclusively, and implemented by national political actors.

3. Our translation.

4. See Dreher/Gaston (2008) for instance.

5. See Amable/Gatti (2006) for instance, on the complementarity between product-market and labour-market institutions. 


\section{CHANGING SOCIO-ECONOMIC MODELS: SOCIAL PROTECTION}

The influence of national political actors on the way the dynamics of capitalism, be it globalisation or one aspect or consequence of it, impacts institutional change can be illustrated with the case of a change concerning one central institutional feature of some socio-economic models, namely social protection. The impact of globalisation on social protection is commonly taken to be twofold: increasing the demand for protection on the one hand because of the economic volatility and structural change it generates; and reducing the possibility for supplying such protection on the other hand because of the increased constraints on fiscal policy and redistribution stemming from competition between nations (Rodrik 1997). These considerations have led to empirical studies testing the link between various indicators of globalisation (foreign-trade-based or other) and the importance or generosity of the welfare state. ${ }^{6}$ At the same time, a political science literature has focused on the impact of political institutions such as the electoral system (majoritarian vs proportional) or the impact of partisanship.

Amable et al. (2006) analysed how economic dynamics and partisanship interact to produce differentiated changes in social protection systems. The general idea is that economic changes do not 'by themselves' lead to institutional change, as in the naïve economic functionalist story, but that the reaction of political actors to these changes will differ according to the social interests they represent. The political equilibrium stemming from the balance of power of the different social groups and the particular features of the electoral system will determine the political hue of the government. Partisanship of the government will determine the way certain economic shocks can lead to transformations of the social protection system in one direction or the other. Left-wing governments may react to increased economic insecurity by augmenting the level of social protection whereas right-wing governments would take the same economic evolution as an opportunity to cut down on social expenditures. In this perspective, the socio-economic models would evolve in reaction to changing economic conditions, but only through the action of the government implementing 'structural reforms'.

An empirical study performed on a panel of 18 developed countries over a period of 18 years considered the interaction between on the one hand a measure of structural change in the industry shares of the value added, a consequence of productive specialisation, and on the other hand the partisanship of the government, appreciated with a proxy for the government's ideological position measured with the help of the relative weight of left and right themes in the government parties' manifestos. The tests concluded to an effect of the government's political hue on the consequences of economic structural change for the evolution of social protection system (the generosity of various social benefits). It was found that left-wing governments strengthened the positive effect of economic shocks on aggregate social expenditure while right-wing governments undertook stronger cutbacks in replacement rates as a reaction to structural change. The reactions to (consequences of) globalisation were therefore significantly different, implying that socio-economic models could take different directions, towards a (neo)liberal or a non-liberal ${ }^{7}$ capitalism, depending on the political choices. Even if a drastic change of model would take time, at least 15 years following the parameter estimations of Amable et al. (2006), it would not be impossible in the context of a significant political change such as the one that followed Margaret Thatcher's political victory in 1979 .

6. See the references in Amable et al. (2006).

7. Cf. Streeck/Yamamura (2001). 


\section{FISCAL COMPETITION}

A socio-economic model is based on a series of socio-political compromises embodied in institutions. This model is politically validated by the support of a dominant social bloc composed of social groups that may have different interests and expectations but are united by a political mediation. As mentioned before, globalisation may directly or indirectly represent a destabilising force for socio-political alliances; for instance, it may favour some groups, which will increase their bargaining power within the DSB and will presumably push forward their demands at the expense of those groups whose economic or social weight waned and bargaining power diminished accordingly. This modification in the respective bargaining powers of the different groups can significantly reduce the space within which political actors may hope to find mediation. In its most severe cases, such situations lead to a political crisis, defined as the break-up of the DSB (Amable/Palombarini 2009).

Globalisation is best not taken as an external phenomenon that would impact national institutional arrangements from the outside, as a set of evolving constraints upon which national political actors and social groups would have no influence. It could in fact be taken by certain socio-economic groups as an opportunity for weakening institutional arrangements that they dislike and favouring the emergence of institutions corresponding more to their expectations. This implies that these groups would also have an interest of deepening globalisation, considering that globalisation itself is defined and constrained or facilitated by a set of institutional features that national political actors partly determine, the implementation of financial liberalisation (Abdelal 2007) or an institutional transformation such as the single market in the EU being typical examples.

The postwar Fordist compromise was once summed up by Lipietz (1984) as a partial and temporary alliance between labour and a fraction of capital. One may consider that the postFordist compromise would be closer to an alliance between capital and a fraction of labour. If this were to constitute the main feature of a new DSB for most developed countries, any policy or institutional change that would unite capital and divide labour would be instrumental in securing a new stable social alliance likely to support a new (neoliberal) socioeconomic model. In this respect, the increasing inequality of income and employment status that has been observed across most developed countries (OECD 2011) should not be analysed as an unfortunate side-effect of a new growth model characterised by a winner-take-all innovation pattern, but more as a structural condition for the emergence of a new DSB supporting a neoliberal model of capitalism.

Amable/Gatti (2005) have modelled a change in the socio-economic framework following one possible consequence of globalisation, namely the possibility for the wealthy to escape from taxation (Alstadsæter et al. 2017). A simple model with three classes - the capitalists and two categories of workers which could either represent the insider/outsider or the high/low skill divide - is used to analyse the change in two dimensions of a socio-economic model regarding social protection. Agents vote on alternative institutional options regarding the extent of employment protection and the level of redistribution. Redistribution is financed by tax revenue and the capitalists have the possibility of partially escaping from taxation, by tax evasion for instance. A study by the French tax administration (Conseil des Impôts 2004) had shown that firms took advantage of various possibilities of escaping from tax obligations without moving production abroad. Capital mobility would not necessarily lead to the relocation of productive activities, but simply the relocation of profits. The preferences of agents regarding the features of the socio-economic model are the following: capitalists prefer low taxation (and 
redistribution) and weak employment protection; low-skilled/unemployed/ outsider workers prefer high taxation/redistribution and weak employment protection; ${ }^{8}$ skilled/insider workers prefer high employment protection level and are ambivalent about the level of taxation/redistribution.

This last point is crucial for explaining the change in social alliances. The model shows that a Fordist-type alliance between capitalists and insiders is possible when capitalists' tax evasion possibilities are below a threshold value. The rationale is that when tax evasion is limited, a large enough part of the tax burden falls on capitalists. A compromise between the expectations of capitalists can be found involving employment protection and some redistribution. However, when tax evasion possibilities increase, the bulk of the tax burden falls on insiders, who become less favourable to redistribution. The socio-economic model evolves, therefore, in the direction of less generous social protection, with more employment flexibility and less redistribution. Globalisation, under the form of capital mobilityinduced tax evasion, reduces the space for political exchange necessary for a socio-political coalition supporting a socio-economic model with a high level of social protection.

The breakup of the DSB has been at the core of the evolution of the French model of capitalism for the last three to four decades (Amable 2017). The institutional transformations of the French model, contrary to the all-too-common cliché of a country that is 'impossible to reform', have been very significant but have not led to the formation of a new stable DSB, a situation defined as a 'structural crisis' (Amable/Palombarini 2009).

\section{DIVERGING GROWTH TRAJECTORIES IN EUROPE}

The question of the type of macroeconomic policy that could be compatible with a particular model of capitalism was relatively neglected until recently. A proposition found in Soskice (2007) was that LMEs would have to conduct a more active and more countercyclical fiscal policy than CMEs because this would correspond to a systemic requirement for each variety. Characterised by a high degree of market flexibility, LMEs would need a more active macroeconomic policy to counterbalance negative economic shocks. CMEs on the other hand would not need such policies because of the automatic stabilisers built into their institutional arrangements and, on the contrary, a conservative macroeconomic policy would stabilise the agents' strategies supposed to be at the root of 'wage moderation', an important element of CMEs' competitiveness. Amable (2009) theoretically investigated the conditions for the validity of this proposition and Amable/Azizi (2014) found it empirically rejected for a sample of developed countries over the 1980-2009 period. Introducing political-economy elements into the picture leads us to envisage the possibility of a complementarity between pro-active fiscal policy and nonliberal institutional features.

Baccaro/Pontusson (2016) recently proposed a so-called 'growth model' approach that finds its inspiration in the works of the French régulation theory (Boyer 1988; Boyer/Petit 1988), which considered jointly the institutional characteristics of the Fordist period and the evolution of macroeconomic variables. ${ }^{9}$ Stable growth was possible, but

8. The rationale is that a higher labour turnover will improve their employment opportunities. However, outsiders are also those that are dismissed first when business conditions deteriorate. Employment protection may therefore protect them to a greater extent than insiders. In fact, the standard assumption about employment protection legislation preferences (that is, outsiders want less labour-market regulation than insiders) is not empirically correct. See for instance Amable (2014).

9. See Boyer (2015) for an overview. 
not guaranteed, if one could find a dynamic compatibility between the productivity gains and the expansion of demand. This depended on the structural parameters defined by the technological regime and the wage-labour nexus. This approach combined both supply-side and demand-side aspects. Revisiting the themes analysed by the regulation literature of the 1980s/1990s, Baccaro/Pontusson (2016) focus on the growth trajectories of developed countries in the context of the crisis of the Fordist model of wage-led growth and a change in the pattern of income distribution favouring capital. Their main results emphasise the contrast between 'consumption-led' and export-led' growth models, epitomised respectively by Italy and the United Kingdom on the one hand and Germany on the other hand; Sweden, by contrast, would represent a case of a 'balanced' growth model where exports and consumption would both drive the country's growth.

Like the original contributions of Boyer (1988) and Boyer/Petit (1988) as well as the abundant post-Keynesian macroeconomic literature (Lavoie 2014), the 'growth model' approach has the advantage over $\mathrm{VoC}$ of introducing the effective demand constraints and the role of demand-sustaining policies alongside considerations about the external constraint in the analysis of the stability of the trajectories of national economies. ${ }^{10}$ This framework was applied to the specific situation of the European Union, and even the eurozone, which gathers export-led and consumption-led countries. The export surplus of the first group are made at the expense of the trade deficits of the second, and this situation seemingly justifies the implementation of austerity policies and 'structural reforms' everywhere, in order to preserve the competitiveness of the first and improve that of the second. The question of the viability of this situation arises in an institutional context where countries cannot change the value of their currency to restore competitiveness (the eurozone) and where economic integration generates a productive specialisation and a geographical concentration that is bound to lead to trade imbalances similar to those that exist within a national state. ${ }^{11}$ But the intra-national specialisation does not raise the same problems as imbalances between nation-states because of the existence of various distribution and redistribution mechanisms that are absent at the supranational level.

Amable (2018) adapts an open-economy Kaleckian model (Blecker 2011) with an investment function depending on the rate of capacity utilisation and the profit rate, a trade balance function depending on the real exchange rate and capacity utilisation, and introduces a public expenditure function incorporating both a counter-cyclical element and a socially determined share of public investment in GDP (Franke 2015), an explicit role for current-account deficit or surpluses and the net foreign asset position as well as the evolution of public and foreign debt in the saving-investment equilibrium. As is well known, it is possible to obtain either wage-led or profit-led regimes in such models, depending on the strength of the profitability effect in the investment function. In addition, foreign trade effects make ceteris paribus the occurrence of a profit-led regime more likely. One may then obtain contrasted configurations, where export-led countries would have a permanent current-account surplus whereas internal consumption-led countries would be characterised by a current-account deficit. In the long term, the question of the sustainability of current-account imbalances arises, as well as that of the public

10. 'Our analytical framework identifies multiple growth models based on the relative importance of different components of aggregate demand - in the first instance, household consumption and exports - and relations among components of aggregate demand. Our "growth models" are more numerous and more unstable than Hall and Soskice's 'varieties of capitalism' (Baccaro/Pontusson 2016: 176).

11. See Celi et al. (2018). 
debt. The model exhibits stable or unstable equilibriums in this respect, depending on the structural parameters. This points to the questionable compatibility between export-led countries, which may find themselves in a stable configuration, and consumption-led countries, which may be in an unstable situation, within the eurozone.

One may investigate whether an austerity policy, which would imply a drop in public expenditure for instance, would actually lead to an improvement or a worsening of the economic situation of national economies. In some configurations, a decrease in public expenditure could improve the long-run economic situation of countries that are in a stable equilibrium configuration. Such presumably export-led economies would end up having a lower public debt-to-GDP ratio and a higher net foreign asset position. This could be interpreted as one possible rationale for the insistence on austerity that Germany has imposed not only on the rest of the eurozone but also on itself. The long-run evolution would be different for countries that are in an unstable configuration, since this could move the country towards a dynamics of increasing public debt and negative foreign asset positions.

\section{CONCLUSION}

The impact of globalisation on the diversity of capitalism can neither be summed up as a monotone convergence towards a unique configuration that mainstream economics would describe as optimal, nor can it be analysed as the reinforcement of specificities of idealised varieties. One must analyse jointly the diversity and the commonalities of capitalism. Developed economies have been subject to significant neoliberal structural reforms, implying various measures of deregulation and liberalisation, for the past few decades. These reforms have had consequences for the diversity of capitalism, affecting some political economies more than others. This paper has argued that the analysis of the dynamic diversity could be performed by considering a political economy of capitalisms based on four elements: the socio-economic model, the dominant social bloc, the political forces, and public policies.

The current transformations in the socio-economic models do not simply involve a change of institutions but also a questioning of past socio-political compromises and political alliances. In this respect, the oft-mentioned salient characteristics of current capitalism, namely the significant increase in income and wealth inequalities as well as in employment statuses, should not be regarded simply as unfortunate side-effects of economic evolution; they are also structural conditions for the emergence of a new dominant social bloc that would support a new model of variegated capitalism. The increase in inequality can be instrumental in breaking up previous communities of interest between different social groups, modifying the relative socio-political weight of these groups and even the social structure and group stratification of societies. This evolution may open up a new political space within which political actors may hope to find a mediation liable to consolidate a new DSB. In this respect, the increasing labour-market segmentation and income/wealth inequality may be necessary for the emergence of a neoliberal regime in most developed capitalist economies.

\section{REFERENCES}

Abdelal, R. (2007): Capital Rules: The Construction of Global Finance, Cambridge, MA: Harvard University Press.

Albert, M. (1991): Capitalisme Contre Capitalisme, Paris: Seuil.

Alstadsæter, A., Johannesen, N., Zucman, G. (2017): Tax Evasion and Inequality, draft. 
Amable, B. (2003): The Diversity of Modern Capitalism, Oxford and New York: Oxford University Press. Amable, B. (2009): Diversity of capitalism and macroeconomic policy, in: Hein, E., Niechoj, T., Stockhammer, E. (eds), Macroeconomic Policies on Shaky Foundations: Whither Mainstream Economics? Marburg: Metropolis-Verlag.

Amable, B. (2014): Who wants the Contrat de Travail unique? Social support for labor market flexibilization in France, in: Industrial Relations, 53(4), 636-662.

Amable, B. (2016): Institutional complementarities in the dynamic comparative analysis of capitalism, in: Journal of Institutional Economics, 12(1), 1-25.

Amable, B. (2017): Structural Crisis and Institutional Change in Modern Capitalism: French Capitalism in Transition, Oxford and New York: Oxford University Press.

Amable, B. (2018): An Open Economy Kaleckian Model with Public Expenditure, draft, University of Geneva.

Amable, B., Azizi, K. (2014): Counter-cyclical budget policy across varieties of capitalism, in: Structural Change and Economic Dynamics, 30(September), 1-9.

Amable, B., Gatti, D. (2005): The political economy of job protection and income redistribution, Working Paper No 2005-12, Paris School of Economics.

Amable, B., Gatti, D. (2006): Labour and product market reforms: questioning policy complementarity, in: Industrial and Corporate Change, 15(1), 101-122.

Amable, B., Palombarini, S. (2009): A neorealist approach to institutional change and the diversity of capitalism, in Socio Economic Review, 7(2), 123-143.

Amable, B., Barré, R., Boyer, R. (1997): Les Systèmes d'Innovation à l'Ere de la Globalisation, Paris: Economica.

Amable, B., Gatti, D., Schumacher, J. (2006): Welfare-state retrenchment: the partisan effect revisited, in: Oxford Review of Economic Policy, 22(3), 426-444.

Aoki, M. (2001): Towards a Comparative Institutional Analysis, Cambridge, MA: MIT Press.

Baccaro, L., Pontusson, J. (2016): Rethinking comparative political economy: the growth model perspective, in: Politics \& Society, 44(2), 175-207.

Blecker, R. (2011): Open economy models of distribution and growth, in: Hein, E., Stockhammer, E. (eds), A Modern Guide to Keynesian Macroeconomics and Economic Policies, Cheltenham, UK and Northampton, MA: Edward Elgar Publishing, 215-239.

Boyer, R. (1988): Formalizing growth regimes, in: Dosi, G., Freeman, C., Nelson, R., Silverberg, G., Soete, L. (eds), Technical Change and Economic Theory, London and New York: Pinter Publishers, 608-630.

Boyer, R. (2005): How and why capitalisms differ, MPIfG Discussion Paper 05/4, Max-PlanckInstitut für Gesellschaftsforschung Köln.

Boyer, R. (2015): Economie politique des capitalismes, Paris: La Découverte.

Boyer, R., Petit, P. (1988): The cumulative growth model revisited, in: Political Economy, Studies in the Surplus Approach, 4(1), 23-43.

Celi, G., Ginzberg, A., Guarascio, D., Simonazzi, A. (2018): Crisis in the European Monetary Union: A Core-Periphery Perspective, London and New York: Routledge.

Conseil des Impôts (2004): La concurrence fiscale et l'entreprise: Vingt-deuxième rapport au Président de la République, Paris: La Documentation Française.

Dreher, A., Gaston, N. (2008): Has globalization increased inequality?, in: Review of International Economics, 16(3), 516-536.

Franke, R. (2015): A simple approach to overcome the problems from the Keynesian stability condition, mimeo, University of Kiel.

Genschel, P. (2002): Globalization, tax competition, and the welfare state, in: Politics \& Society, $30(2), 245-275$.

Hall, P., Soskice, D. (eds) (2001): Varieties of Capitalism: The Institutional Foundations of Comparative Advantage, Oxford and New York: Oxford University Press.

Howell, C. (2003): Varieties of Capitalism: and then there was one?, in: Comparative Politics, 36(1), 103-124.

Kalecki, M. (1943): Political aspects of full employment, in: Political Quarterly, 14(4), 322-330.

Lavoie, M. (2014): Post-Keynesian Economics: New Foundations, Cheltenham, UK and Northampton, MA, USA: Edward Elgar Publishing. 
248 European Journal of Economics and Economic Policies: Intervention, Vol. 15 No. 2

Lipietz, A. (1984): L'audace ou l'enlisement: Sur les politiques économiques de la gauche, Paris: La Découverte.

OECD (2011): Divided We Stand: Why Inequality Keeps Rising, Paris: Organisation for Economic Cooperation and Development.

Rodrik, D. (1997): Has Globalization Gone Too Far?, Washington, DC: Institute for International Economics.

Soskice, D. (2007): Macroeconomics and varieties of capitalism, in: Hancke, B., Rhodes, M., Thatcher, M. (eds), Beyond Varieties of Capitalism, Oxford: Oxford University Press, 89-121.

Streeck, W. (2010): E pluribus unum? Varieties and commonalities of capitalism, MPIfG Discussion Paper 10/12, Max-Planck-Institut für Gesellschaftsforschung, Köln.

Streeck, W., Yamamura, K. (eds) (2001): The Origins of Nonliberal Capitalism: Germany and Japan in Comparison, Ithaca and London: Cornell University Press. 